\title{
Catechization and Conversion
}

\section{A Comparison of Two German Jesuit Plays on the Life of St. Augustine}

\author{
Elizabeth Ellis-Marino
}

Ph.D. candidate, Late Medieval and Renaissance Studies, University of Arizona lizzyem@email.arizona.edu

\begin{abstract}
The conversion of large portions of the German-speaking world from Protestantism to Catholicism in the late sixteenth and early seventeenth centuries is considered to be one of the successes of the European Counter-Reformation and of the Jesuits. However, Catholicization programs, especially those supported by the territorial governments, were not received without resistance. In both embattled and secure areas, the Jesuits viewed their schools as primary to their mission to reclaim Protestants and to solidify Catholic faith. Drama was one of the most visible ways that Jesuit teachers could reach the general populace for this purpose. Conversion and saints' lives were common themes in Jesuit plays across Europe. One of the most popular of these plays which contributed to the process of Catholic confessionalization was the German Jesuit play Augustinus conversus by Jakob Gretser, first staged in the staunchly Catholic city of Ingolstadt. In the aftermath of an armed rebellion against the Counter-Reformation in the territory of Paderborn, the Jesuits staged a comedy by Augustinus Turranius which drew heavily on Gretser's play. In staging a comedy about the adolescence of St. Augustine, the Jesuits expounded on the themes of conversion, redemption, and forgiveness without directly referring to the situation in Paderborn. In this paper, both plays are placed within the context of the cities in which they were composed and performed, and the religious struggles in both cities are considered in the light of the larger Jesuit missionary project of the sixteenth and seventeenth centuries.
\end{abstract}

\section{Keywords}

Paderborn - Ingolstadt - Germany - Holy Roman Empire - Jesuit school drama Counter-Reformation - St. Augustine - Paderborn - Jakob Gretser - Augustinus Turranius - conversion 
The system of schools for boys developed by the Society of Jesus in the sixteenth century was one of the crowning achievements of the CounterReformation. In addition to providing a generally excellent Humanistic education in Latin, Greek, and rhetoric, the Jesuit schools were also designed to raise up convinced Catholics with a strong sense of moral rectitude, not only from among the students, but also from the wider communities in which the schools were situated. The schools became so important to the Society that, in 1560 , Juan Alfonso de Polanco divided the order's strategies "for helping our neighbors" into two categories: the schools and everything else. ${ }^{1}$ Later, upon visiting the Jesuit college in Rome in 1580, Michel de Montaigne remarked in his journal:

It is amazing to see what this college means in the Church. I think there never was an association or body among us which quite equaled this, nor one that produced results such as these men will produce if their plans prosper. This is a nursery of great men, of all species of greatness. No other group is so formidable to the heretics of our day. ${ }^{2}$

Of course, the mission of raising up Catholics of strong conviction depended a great deal upon the different local circumstances in which Jesuits found themselves teaching. In staunchly Catholic areas, the Jesuits were primarily tasked with educating the already-Catholic sons of the local population, and making them into the "great men" about whom Montaigne wrote. In confessionally mixed areas, the Jesuits had the ability to reach non-Catholics through their schools. Thus, the establishment of Jesuit schools in areas where both Protestants and Catholics lived contributed to a larger Jesuit mission of rolling back the advances Protestantism had been making in Europe.

One of the ways Jesuit educators attempted to reach both students and the wider communities they hoped to further Catholicize was through the staging of plays open to the public. Two such plays are examined in this paper, both of which treated the same subject matter: the life of St. Augustine of Hippo. One, The Comedy of St. Augustine's Childhood and Youth by Augustinus Turrianus (1566-1644), was composed and staged in Paderborn, a town in northwestern

1 John W. O'Malley, "The Society of Jesus," in Religious Orders of the Catholic Reformation, ed. Richard DeMolen (New York: Fordham University Press, 1994), 150.

2 Quoted in William H. McCabe, An Introduction to the Jesuit Theater, ed. Louis J. Oldani (St. Louis: The Institute of Jesuit Sources, 1976), 30. Montaigne was participating in the larger polemical tradition of referring to Protestants as "heretics." 
Germany. ${ }^{3}$ The Jesuits there, although supported by the prince bishop, faced a significant population of Protestant townspeople, who were resistant to their efforts to convert the area wholly to Catholicism. The other, Augustine Converted: A Drama, was composed by Jakob Gretser (1562-1625) and staged in Ingolstadt where the Jesuits had the support of the ruling dynasty. ${ }^{4}$ While the play in the securely Catholic Bavarian city of Ingolstadt deals with Augustine's conversion in a creative yet entirely orthodox way, the play in Paderborn presents Augustine as a naughty child who needed to come under the tutelage of an older authority figure. By comparing two plays on similar topics composed in two different political settings, the nature of Jesuit plays as instruments of both catechization and Catholicization is revealed.

Latin plays written by Jesuits for performance by schoolboys comprise one of the most dynamic and widespread literary and performative genres of the Baroque period. There are records of plays composed and performed in such far-flung places as Mexico City, Transylvania, and the Portuguese colony of Goa in western India. ${ }^{5}$ The plays treated such varied subjects as saints' lives, Roman history, legends from early Christianity, and the dilemmas of Christians in Japan. ${ }^{6}$ They were performed at all levels of Jesuit schooling — by young boys in Jesuit secondary schools, by older students in Jesuit colleges, and by students in Jesuit seminaries. ${ }^{7}$ In the late sixteenth and seventeenth centuries, high-ranking members of the Society considered plays integral to the educational program in their collegia. ${ }^{8}$ It appears that thousands of these staged events were put on by students under Jesuit tutelage between the 1550 and the $1770 s$, the era of the suppression. Each Jesuit school staged a play at least twice a year, once during carnival and once during their awards week ceremonies. ${ }^{9}$

As a staged genre, plays are by their nature specific to the time and place in which they are performed. Jesuit plays were generally written by a Jesuit who was a teacher at a secondary school for performance by a specific group of students. The fact that many of these places appear to have been staged only a

3 Augustinus Turrianus, S.J., Comoedia de Divi Augustini pueritia et adolescentia, ed. and trans. Peter Martin Maier (Aachen: Shaker, 2006).

4 Jakob Gretser, S.J., Augustinus conversus: ein Drama, ed. and trans. Dorothea Weber (Vienna: Österreichischen Akadamie der Wissenschaften, 2000).

5 McCabe, Jesuit Theater, 270-274.

6 Ibid., 3 .

7 Ibid., 32 .

8 Jonathan Levy and Floraine Kay, "The Use of the Drama in Jesuit Schools, 1551-1773," Youth Theatre Journal 10 (1996): 55-66.

9 Paul Shore, "Baroque Drama in Jesuit Schools of Central Europe, 1551-1773," The History of Universities 20/1 (2005): 159 . 
few times in only one locality makes their historical settings key to understanding them..$^{10}$ However, little information survives about the staging of most Jesuit plays. Because the Society considered dramatic writing less important than homiletic or apologetic writing, texts of plays in many cases have survived only accidentally. ${ }^{11}$ It appears that no systematic effort was made to save materials related to Jesuit school drama. In one case the text of a play was bound together with funeral sermons. ${ }^{12}$ Records pertaining to the plays are therefore spotty and not widely available.

In addition to providing a reinforcement of the Latin curriculum, the plays were designed to communicate the values of the Counter-Reformation to both actors and audience. As such, they are similar in content to other less formal genres of catechization, such as songs. ${ }^{13}$ The Ratio studiorum (1586), a manual for Jesuit educators, features comments on the usefulness of the plays in forming favorable attitudes in the wider community toward the Society in general: "Our students and their parents become wonderfully enthusiastic, and at the same time become very much attached to our Society, when we train the boys to show the results of their study, their acting ability, and their ready memory on the stage. Hence, we recommend that comedies and tragedies should be performed."14 The manual also contains a recommendation that Jesuit educators organize at least two public stagings of Latin drama, and a number of smaller recitals of poetry or drama written by upper-level students for an audience of their schoolmates and teachers. From the beginning, the performances were intended for the public as well as for the students. In order to reach non-Latinized segments of the population, synopses in the vernacular were handed out to the audience before the play began. ${ }^{15}$ These were usually handwritten by the students with the best handwriting. ${ }^{16}$

10 Although some plays, like Jacob Biedermann's Cennodoxus and Cosmoarchia were considered classics, and were staged in Jesuit colleges across the world throughout the seventeenth century, these plays were the exception rather than the rule.

11 Shore, "Baroque Drama," 148.

12 Ibid., 149.

13 For a discussion of catechetical songs, see Theo van Oorschot, "Katechismusunterricht und Kirchenlied der Jesuiten (1590-1640)," in Literatur und Volk im 17. Jahrhundert: Probleme populärer Kultur in Deutschland, vol. 1, eds. Wolfgang Brückner, Peter Blickle, and Dieter Breuer (Wiesbaden: Wolfenbütteler Arbeiten zur Barockforschung 1985), 543-558.

14 Quoted in McCabe, Jesuit Theater, 13.

15 Levy and Kay, "Uses of Drama," 59. It is possible that these synopses were used by weaker Latin students as well.

16 Later in the seventeenth and eighteenth centuries, when the larger, richer Jesuit colleges owned their own presses, some of these synopses were printed in-house. However, for the early period, what survives is almost entirely hand-written. 
Plays were huge undertakings. Many of them required original composition, or at least extensive copying of an existing work. The expense of stage sets and costumes was far from negligible. Surviving descriptions and illustrations of Jesuit plays show that the costumes, props, and sets were often quite elaborate. A list of props needed for one seventeenth-century play in Cologne included fireworks, twelve horses, an eagle, a lion, a seven-headed beast ("to be torn apart by the lion and eagle"), and several biers, with coffins on them. ${ }^{17}$ The coffins were to be decorated as if they belonged to prominent German noblemen. The set was to depict the city of Jerusalem. In non-university settings, the young actors were often hard to control, and sometimes did not apply themselves in memorizing their lines. Although the Society was vocal about the usefulness of the drama, it was far from a painless undertaking.

The Jesuits took pains not to associate themselves with other dramatists. The Society consistently condemned groups of traveling players. Although in some countries, it was common to see women on the stage, they were prohibited from all Jesuit theater. ${ }^{18}$ Early on, the Society prohibited the boys to dress like women, although this stricture was dropped by the $1570 \mathrm{os}$. As for the content of the plays, the Roman College in 1575 gave this advice to the Italian schoolmasters:

Not only must plays involve nothing vile or unbecoming, but they must not even contain a hint of such things. Similarly, it is not enough that they should deal with matters that are neutral, not bad, or merely good; they must be thoroughly pious and religious. They must, of course, not hurt morals; but they must vigorously uplift and edify. If not, let there be no plays. ${ }^{19}$

Although the plays tended to eschew the lewd subjects often displayed by traveling players, they still made reference to those things that imperiled the soul. To do otherwise would be to write plays without dramatic tension. What perils were appropriate to talk about were specific to the time and place of the plays' composition. The two plays on Augustine written by Turranius and Gretser make this clear. While Gretser, with the Ingolstadt Jesuits who enjoyed a high status in the city and the patronage of a powerful and wealthy family, openly discuss Augustine's heretical Manichaeism, Turranius, with the Paderborn

17 McCabe, Jesuit Theater, 6o. Obviously the eagle, lion, and horses were props, rather than live animals.

18 McCabe, Jesuit Theater, 14.

19 Quoted in ibid., 24. Although this letter recommends "thoroughly pious and religious" plays, classical subjects were commonly dramatized, and considered acceptable exempla for the students. 
Jesuits who were in the midst of re-conquering a territory for the church, made no mention of Augustine's heretical youth.

In writing their plays, Turranius and Gretser were drawing on an existing tradition of dramatizing the life of St. Augustine. The earliest surviving Latin play on the life of Augustine dates from 1427, at a time of "rediscovery" and renewed appreciation of Augustine's prose in the era of the early Humanists. ${ }^{20}$ Augustine's writings about his youth were by the turn of the seventeenth century very well known among educated Europeans, including many Protestant theologians who found much that was theologically appealing. As retold by the Jesuits, the story of Augustine's life was one of moving from utter dissipation marked by heresy and concubinage to a stainless, virtuous life. For priests dedicated to beating back the influence of heresy and sin in the world, the story of a man turning from the vices of lust and heresy to a virtuous life within the Catholic Church had obvious utility. The Jesuit playwrights can therefore be seen as reclaiming Augustine for their Counter-Reformation struggle, rather than allowing him to be associated primarily with the new religion.

\section{Catechization:Jakob Gretser in Ingolstadt}

Gretser's Augustinus conversus, or Augustine Converted, was a wildly popular play. Copies of it appear in the inventories of Jesuit college libraries from Spain to Eastern Hungary. ${ }^{21}$ Written by one of the great seventeenth-century Jesuit playwrights, the play portrays Augustine as a complex figure full of inner turmoil. As such it is one of the more compelling extant Jesuit plays. ${ }^{22}$ Its complex portrayal and explicit discussion of Augustine's Manichaean youth are reflective of the sophisticated, strongly Catholic audience for which the play was intended. Familiar with the community of Ingolstadt and the student body of the Jesuit college, Gretser felt safe enough to write a sophisticated depiction of salvation and the vices that imperiled the soul, chief among which were lust and heresy.

Jakob Gretser was born at Markdorf in the Diocese of Constance. He entered the Society of Jesus in 1578 , and nine years later he defended publicly theses

20 Gretser, Augustinus conversus, 10. Augustine was never entirely forgotten in Western Christendom, but the rise of Humanism allowed his writings to be more widely read and appreciated.

21 Gretser, Augustinus, 11.

22 Gretser's name is spelled either "Gretser" or "Gretzer," with little consistency in the sources. However, I have chosen to use "Gretser" because it is more common in Englishlanguage discussions of him. 
covering the whole field of theology. ${ }^{23}$ He spent most of his life at the Jesuit college in Ingolstadt where he taught philosophy for three years, dogmatic theology for fourteen years, and moral theology for seven years. In addition to his dramatic writings, of which twenty-one individual plays survive, he also wrote anti-Lutheran and anti-Waldensian polemics, apologia for several popes and one for the Society, and an archaeological investigation into the cross of Christ, along with an extended discussion of the theology of the cross.

At Ingolstadt, Gretser was a luminary. In the late sixteenth century the college itself was known as the most dynamic in the German-speaking lands. During Gretser's time there, the college boasted an astronomy faculty and a physics professor. ${ }^{24}$ It was closely attached to the University of Ingolstadt, where chairs in theology and rhetoric were reserved for Jesuits. ${ }^{25} \mathrm{~A}$ theater for staging plays was completed in 1590, and, by all accounts, the plays were well attended by Ingolstadt's citizenry. ${ }^{26}$

Augustinus conversus, first staged in 1592, dramatizes Augustine's conversion experience as recounted in the Confessions. It is set during his time in Milan, and covers his relationship with Ambrose. Augustine's mother, St. Monica, has a major role in the play, serving as a sort of chorus to Augustine:

Out of thirsty Africa to Italy I followed my son, who has strayed from the proper way of belief and of good morals. Would that he would be taken from the darkness this day, with whom I would be united through the ceremony of the Catholics [casto Catholicorum]. To have born him angers and shames me, if he does not abandon the nefarious sect of the Manichaeans and the filth of shameful lust. What a happy mother I would be, should he put down all things he praises. With such a son I am blessed. But you, supreme governor and judge of the world, look favorably upon my sigh, look upon my tears, that I send forth for my son. ${ }^{27}$

23 Eugene Deviln, Jacob Gretser and the German Jesuit Drama in the Sixteenth Century (Lexington: Lexington Literature Series, 1973), 35 .

24 Joseph S. Freedman, "Professionalization' and 'Confessionalization': The Place of Physics, Philosophy and Arts Instruction at Central European Academic Institutions During the Reformation Era," Early Science and Medicine 6 (2001): 340.

25 Karl Hengst, Jesuiten an Universitäten und Jesuitenuniversitäten: zur Geschichte der Universitäten in der Oberdeutschen und Reinischen Proinz der Gesellschaft Jesu im Zeitalter der Konfessionellen Auseinandersetzung (Paderborn: Schöningh, 1981), 174.

26 Gretser, Augustinus, 9 .

27 Ibid., 78. 
Augustine himself is a character full of inner turmoil throughout most of the play, trying to decide which path to choose. Under the influence of his mother, he declares early in the play, "I find no modicum of peace, and I am no longer comforted by my previous comforts. Away with you, Heresy! Away, Lust! Let you have your affairs for yourself, no more shall you be my friends." ${ }^{28}$ Nevertheless, he falls back in with his heretical friends midway through the play. With the help of his mother and St. Ambrose, he eventually finds inner peace when he converts from Manichaeism to Catholicism. The play concludes in a post-baptismal scene with Monica, Augustine, and Ambrose:

AMBROSE: The celebration of your baptism is concluded, Augustine. Now that you have been wet and purified by holy water, may you live in faith, in which you have been bound to God by an oath, may you always keep this cleanliness and henceforth happily and willingly serve all as a servant, in order to remove the heavy yoke of Heresy and the filth of Lust. [...]

MONICA: How many women are as happy as I? How many happier and more blessed than I? [...] Willingly and happily I will carry out your will, now that I know my son has been doused with holy baptism. I desired and wept for with many tears. What thanks, then, blessed Bishop, can we give to you for your diligence? [...]

AMBROSE: Hold off! You owe me no thanks, except to that out of this abundant source good things may flow [...]. Obey the creator and maintainer of all things, Augustine [...]. I see that you will be a bright light of the world and a great, keen-minded, apologist of the holy religion. And you, blessed mother of a blessed son, God shall fulfill your wishes richly. ${ }^{29}$

The Catholic Church is presented in this play as the ultimate source of righteousness and happiness. Monica, Augustine's mother and most vocal source of morality in the play, can be seen as a Marian figure, suffering as she watches her son descend into heresy, and celebrating when he finally enters the Catholic fold. To be happy, free of vice and secure in oneself, one has to come under the tutelage of a holy woman who is distinctly Catholic in her beliefs, and also a

28 Ibid., 8 o.

29 Gretser, Augustinus, 194-196. 
wise bishop..$^{30}$ One's conversion to the path of righteousness is celebrated with the sacrament of baptism.

Augustinus conversus was, therefore, a continuation of Gretser's apologetic, pro-Catholic writings. Although Ingolstadt was a Catholic city, its importance as a trading center meant that the residents had contact with Protestants. In the late sixteenth and early seventeenth centuries, the competing faiths of Western Europe were attempting to solidify their power bases and reinforce the beliefs of their followers while denigrating their competition in a process historians have called "confessionalization." For Gretser and others like him, it was paramount to remind even the strongly Catholic audiences of the Ingolstadt Jesuit playhouse that Catholicism was the right and moral religion. Heresy was therefore presented as "straying from the path of good morals." Although the specifics of Manichaeism were never discussed, the allusions to leaving the orthodox faith for another form of Christianity could not have been missed by Gretser's audience.

In Ingolstadt, the Jesuits and their students performed in front of a wellCatholicized audience. They therefore openly discussed Augustine's heretical past without worrying about giving ammunition to the Protestants, or inadvertently tempting some in their audience toward Protestantism through their plays' content. Nevertheless, Gretser and others in similar positions could not resist the story of St. Augustine, in which righteous men and women eventually choose the orthodox faith, represented by a bishop and a long-suffering mother figure. Although as a well-crafted example of Catholic Baroque drama it found wide acceptance throughout the Jesuit world, Gretser's play is inseparable from the strongly confessionalized milieu in which it was composed.

\section{Conversion: The Jesuit College in Paderborn}

In contrast to Gretser with his relatively sophisticated treatment of the themes of sin and redemption, Turranius in his Comoedia de Divi Augustini pueritia et adolescentia, or The Comedy of St. Augustine's Childhood and Youth, which was first staged in Paderborn in 1604, cleaved far more closely to the admonition that plays not even contain a hint of unacceptable content. Originally staged when the city and territory of Paderborn was recovering from open rebellion against the bishop and his Jesuits, the play itself is a much more straightforward discussion of right and wrong. The history of the principality in which it

30 The play includes a brief discussion of Monica's relic collection, some of which she gives to Ambrose, much to his joy. 
was composed provides some insight into the milieu in which the play was first performed.

By 1585, when Bishop Dietrich von Fürstenberg ascended to the cathedra in Paderborn, the cathedral chapter, of which he had been the dean since 1577, had long found itself under confessional siege. In the last two thirds of the sixteenth century, the religious question in the prince-bishopric of Paderborn was far from settled. The Protestant cause in Paderborn reached its acme in the years 1577 through 1585, under the episcopacy of Heinrich von SachsenLauenburg. The second son of a prominent Lutheran duke, Sachsen-Lauenburg held the titles of archbishop of Hamburg-Bremen and bishop of Osnabrück at the time of his ascension to the cathedra in Paderborn (although his holding of these episcopacies was accepted neither in Rome nor in Cologne). ${ }^{31}$ Both of these titles came with extensive political holdings. Sachsen-Lauenburg was openly Protestant, supporting both Lutherans and the Reformed who fell under his rule. Under his administration the city of Paderborn and its surrounding countryside began to take on more of the character of Protestant lands. The remaining monasteries and convents were closed, the clergy was encouraged to marry, and services were conducted in German. Visitations conducted after Sachsen-Lauenberg's reign ended in 1585 show that these reforms were carried out to some success in the countryside, and to almost total success in the city of Paderborn. ${ }^{32}$

Early in 1585 , it seemed as though the city and rural territories of Paderborn were well on their way to becoming Protestant. In January of that year, Fürstenberg invited the Jesuits into the city of Paderborn. Apparently, the Jesuits were not wholly unwelcome in the city. Instead of being tortured, executed, or expelled from the bishop's lands, they apparently found a stronghold in the city's gymnasium. By the time of Sachsen-Lauenburg's sudden death in March of 1585 , the gymnasium was fully infiltrated by Jesuit priests. Although the townspeople of Paderborn appear to have accepted Sachsen-Lauenburg's reforms quietly, the initial success of the Jesuits points to some resistance to Protestantism among the city's people.

After the death of Sachsen-Lauenburg, who was thrown from a horse in March of 1585 and died soon after, Fürstenberg, the aforementioned dean of the cathedral chapter, was elected bishop of Paderborn. The ascension of

31 Hanz Jurgen Brandt and Karl Hengst, Geschichte des Erzbistums Paderborn, vol. 2 (Paderborn: Bonifatius, 2007), 173.

32 Karl Hengst, "Kirche und Konfessionsbewußtsein im Klerus des 16. Jahrhunderts," in Ecclesia Militans: Studien zur Konzilien- und Reformationsgesichte, ed. Walter Brandmüller (Paderborn: Schöningh, 1988), 596. 
Fürstenberg to the cathedra in Paderborn represents a turning point in the confessional fortunes of the area. Under Fürstenberg, who ruled the area from 1585 until his death in 1618, the city of Paderborn became a stronghold of Catholicism and a center for a militant reconquest of the countryside for Catholicism.

In 1592, Fürstenberg founded a Jesuit college in the city, in the former cloister of the Friars Minor. The stated reason for the founding of a college in the city was to prevent the youth of Paderborn from the undue burden of having to leave the territory to study at institutions in neighboring territories. ${ }^{33}$ The charter specifically mentions the college at Marburg, a Protestant city. In 1605 , a new building was constructed specifically for the Jesuit college, thus making the Society's presence in the city appear more permanent. The spiritual reconquest of the city of Paderborn was carried out almost exclusively by the Jesuits, and the college was one of their primary weapons.

However, the reconquest of Paderborn was not without significant resistance. In 1604, the countryside almost exploded into religious war. In April of that year, the Protestant Landgrave of Hesse-Kassel amassed troops along his border with the territory Paderborn "to protect the rights of the knighthood." ${ }^{34}$ These troops were joined by several of Paderborn's territorial nobles, some villagers from the countryside, and several prominent townspeople from the center city, including the mayor. Fürstenberg responded by placing troops of his own on the same border. Despite the evident tension between the two neighbors, their respective armies were sent home with no shots fired. ${ }^{35}$ Although the confrontation ended bloodlessly, there were violent consequences. The mayor of the city of Paderborn suffered a traitor's death. After his execution, his body was displayed at the city gates as a warning to other traitors. The territorial nobles, whose rights were the stated reason for the confrontation, were not punished for their actions.

It was in this climate that The Comedy of St. Augustine's Childhood and Youth was performed in at the Jesuit college in the city in November 1604. Composed by Fr. Augustinus Turrianus, a local Jesuit about whom there is almost no archival information, the play was staged in the Jesuit college and well-attended by the people of Paderborn. ${ }^{36}$ Although still in its early stages of development,

33 Hengst, Kirchliche Reform im Fürstbistum Paderborn unter Dietrich von Fürstenberg (15851618) (Paderborn: Schöningh, 1974), 52.

34 Bastian Gilner, Unkatholischer Stiftsadel: Konfession und Politik des Adels im Fürstbistum Paderborn (1555-1618) (Münster: Ardey-Verlag, 2006), 55.

35 Hengst, Kirchliche Reform, 15.

36 There appears to have been no connection between this Fr. Turrianus and the Spanish Jesuit polemicist Francisco Torres, who is also known as Turrianus. 
Jesuit comedy was nevertheless at this time already a standardized affair. The characters in these comedies were broadly drawn, so that the audience could immediately tell who was on the side of good and who was not, and who therefore was worthy of ridicule. ${ }^{37}$ Comedic scenes often consisted of verbal sparring between two characters, where the character on the side of good had the upper hand. Jokes turned on wordplay and made the character on the wrong side look like a buffoon. Although intended to entertain, even Jesuit comedies were clear in their didactic and moral agenda.

Comedy was considered the more popular and common of the two genres, and more likely to draw the public into the theater. The Roman College advised schoolmasters not to stage two public tragedies in a row, because the people would tire of such heavy material. ${ }^{38}$ Comedies were recommended in order to keep school theatrics appealing and well attended. The Jesuits in Paderborn likely chose to stage a comedy centering on the question of conversion in order to make their message more appealing to a citizenry who had just experienced the violent side of the Jesuits' Counter-Reformation zeal.

The play stars Augustine, his friends, who are rowdy blockheads, and St. Monica. It draws heavily on Gretser's play, sometimes lifting whole speeches from it. However, instead of concentrating on his conversion in the Confessions, the play recounts a time in Augustine's childhood when one of his friends dies and he is confronted with his own mortality. ${ }^{39}$ He convinces himself he is dying, converts to Christianity, is saved, and —one is led to believe-lives virtuously ever after.

The comedy centers on verbal jousting. Monica, the representative of orthodox Catholicism, always has the upper hand. Young St. Augustine is the butt of jokes in this play. In several instances in the play, Monica verbally traps Augustine into admitting that the right course is to become a Catholic. In the following excerpt, Augustine has convinced himself that he is dying, and has just told his mother.

MONICA: And I, who am wounded from sorrow, will you leave me so, dear son?

AUGUSTINE: Please spare me, Mother!

37 McCabe, Jesuit Theater, 45 .

38 Shore, "Baroque Drama," 150.

39 Although a similar incident is recounted in Book Four of Confessions, Augustine was in his twenties when his childhood friend died. However, the Augustine of this play appears to be eleven or twelve. The play can therefore be seen as being only loosely based on the Confessions, if at all. 
MONICA: Your mother knows: your mother searches your expression and body language. Do you see how you have stuck your hands out? Do you want me to send for a priest, so that he can be washed in the clear waters of baptism? ${ }^{40}$

Despite the play's centering on the question of conversion, and despite the author's having drawn heavily on Gretser's play, the characters never mention Manichaeism. The solution to Augustine's dilemma is to be baptized by a priest ("presbyterus"), and live a virtuous life. Although Augustine seems to unconsciously desire the sacraments of Christianity, he is portrayed essentially as a bad boy with the potential to be good, under the influence of several wrongheaded friends.

Why, in a place where "heresy" was on everyone's mind, was the danger Augustine put himself into when he flirted with Manichaeism not discussed? The answer can be found in the concern that the plays not contain any hint of impropriety. To talk openly and frankly about "heresy" with the people of a city that had just experienced open rebellion based on Protestantism seemed too close to impropriety. Instead of tempting the people of Paderborn with a depiction of forbidden religion, Turrianus instead portrayed Augustine as a naughty child, who needed formal schooling to tear him away from the vice of ignorance, and to bring him toward proper Catholic behavior. Therefore the story of young Augustine ends before he falls into the clutch of the vices of heresy and lust.

The third act of the play, which departs entirely from the plot, proves that the author was at pains to inculcate his audience with ideas of proper behavior. In the last act of the play, Augustine has almost no lines. Instead, he is a nearly silent witness to dialogue between allegorical figures: Wisdom, Ignorance, Good Behavior, and Bad Behavior. The characters admonish Augustine and the audience to apply themselves diligently to study, particularly learning their prayers. Good Behavior says, for example, "Learning is a second sun for the world, or at least it is not less important for the world as the sun. Learning is certainly more useful, if understanding is more important than the eyes: the sun provides light for the eyes, the other for the thoughts." ${ }^{41}$ Augustine is also admonished by Wisdom to improve his Greek and Latin, and to begin to learn Hebrew, as he is destined to be Wisdom's attendant:

\footnotetext{
40 Turrianus, Comoedia de Divi, 292. Comedy in this scene derives in part from the fact that the original audience, which included the actors' parents, was watching teenage boys re-enact the mother-child relationship.

41 Ibid., 396.
} 
Augustine, you should be my attendant, I would rather you were given wisdom. Take truth and heavenly knowledge as good guides for your way [...]. [addressing Ignorance] Do you always turn young hearts with your fraudulent caresses? I claim this young man. Augustine, never leave my side: speak only for me, and love triumphs. ${ }^{42}$

These allegorical speeches, which are common in Renaissance and Baroque drama, allowed Turrianus to present to the audience an explicit program of good behavior. In contrast to Augustine's earlier behavior in the play, Wisdom and Good Behavior teach Augustine and the audience how to remedy their previous errors.

The play ends with the awarding of prizes for the best students of rhetoric, prose, and poetry for the year. The prize announcements are followed by short prepared speeches for each member of the school's faculty, in which they address the audience and explain how their work improves the fabric of the community. Typical of the tone of these speeches is one to be given by professors of humanities: "You hurry to run through the second of the Aonian sources yourself, in order to drink from the holy stream of Bacchus. No fastidiousness slows this course: for Phoebus colors the foreheads of the tired with the spring of perennial waters." ${ }^{33}$ Thus is the audience, including especially students, admonished not to leave off their studies early to go drinking. Apparently, the solution to Augustine's troubles is to behave himself as a proper student, obedient to those in authority and diligent in his work.

Rather than present a heretical Augustine's return to Catholicism, Turrianus instead chose to portray the young Augustine as a negative example to his students. Rather than a good soul mired in heresy and sin, Augustine was simply a disobedient child. Much like a disobedient student experienced corporal punishment, the people of Paderborn had just witnessed the physical punishment of their civic body, and Turranius's play reinforced the message of that punishment. It admonished them to apply themselves diligently to their stations in life. The Jesuit's refusal to acknowledge Augustine's heresy was a safeguard, lest the play tempt Paderborn back into its former ways.

Unlike in Ingolstadt, where Gretser could dramatize the dilemma of the soul with some degree of liberty, Turrianus clearly did not trust his audience. Rather than reflecting the dilemma of the soul so apparent in Augustine's biographical writings Turrianus's dramatization of Augustine's life presented a clear behavioral program for his audience. The audience was instructed to

$42 \quad$ Ibid., $378-380$.

43 Ibid., 430. 
obey authority figures (represented by St. Monica, the allegorical figures of the third act, and the teachers in the fourth act) and dedicate themselves to a given task. Thus Turrianus's play was an extension of the effort of the Jesuits in Paderborn to establish and reinforce their authority over the townspeople. Where Gretser's play reflected a sophisticated, albeit morally clear, worldview likely shared by both the author and the audience, Turrianus's play reflected a desire for social order and obedience on the part of the author as he and his fellow Jesuits confronted the tense situation in the city of Paderborn in late 1604. Thus, when considered in their original milieu of composition and performance, these two plays reveal not only the varying political positions of different Jesuit colleges, but also the specific social conditions of the audience, as perceived by two Jesuit authors.

Although many Jesuit plays survive only in their vernacular synopses, and still more only appear in school records as having been performed, the extant body of Jesuit Latin school drama is still immense. Comparative examinations of these plays, as well as the situation for which they were composed, gives the historian insight into the mental world of the Jesuit educators of specific times and places. How the authors viewed the public for which their plays were performed, the political situation in which they operated their schools, and the moral values they wished to impart to their students and the general public are all reflected in these plays.

Early modern Jesuits' recurrent complaints about having to stage school plays are well known to scholars of Jesuit drama. ${ }^{44}$ That such complaints were widespread in Europe itself underscores how important they were to the Society's mission. Despite the cost and headache of staging a play, new compositions and re-stagings of classics such as Augustinus conversus and Jacob Biederman's Cennodoxus were persistent from the late sixteenth century through to the era of the Society's suppression. That two-hundred-year period witnessed some of the most profound changes in European history, from the aftermath of Reformation gains and the flowering of Catholic culture to the Thirty Years' War and the rise of Absolutism. Given what is already known of the Society's near constant cultural and political engagements in that era, Jesuit school plays - studied with reference to the local contexts in which they were publicly staged - are a relatively untapped historical source for the social history of Jesuit education, but also of the Society's Counter-Reformation catechetical and conversion strategies. 